A. avenae; uninoculated tubes served as controls and treatments were replicated ten times. After 6 weeks, the inycclium was almost completely destroyed in tubes to which $100 \mathrm{~A}$. avenae had been added. The compost had the typical wet appearance and smell often associated with the presence of many parasitic nematodes. The estimated average populations of $A$. avenae in the tubes after 6 weeks were: controls, $0 ; 10, A$. avenae/tube, $43.000 ; 100 \mathrm{~A}$. avenae/tube, 146,000 .

These oluservations show that $A$. avenae can seriously damage mushroom mycelium and could be harmful to mushroom production. This nematode occurs commonly in soil. hence it could easily be introduced into mushroom beds. However, it is not eommonly a mushroom pest. A. avenae is readily killed at $60^{\circ} \mathrm{C}$., and, like other parasitic nematodes, is controlled by the 'peak heating' of compost often practised in mushroom production.

\section{J. HOOPER}

Rothamsted Experimental Station. Harpenden, Herts.

${ }^{1}$ Cairns, E. J., Phytopath., 42, 4 (1952).

${ }^{2}$ Franklin, M. T., Nematologica, 2, 306 (1957).

${ }^{3}$ Goodey, J. B., Nematologica, 3, 1 (1958a).

4 Goodey, J. B., Nematologica, 3, 91 (1958b).

${ }^{5}$ Goodey, J. 13., Ann. App. Biol., 48, 655 (1960).

'Bastian, II. C., Trans. Linn. Soc. Lond., 25, 73 (1865)).

\section{Micro-organisms under a Simulated Martian Environment}

Many investigators speculating on the environmental conditions of Mars have concluded thet some form of life exists there ${ }^{1-5}$. Fulton et al. ${ }^{6,7}$ have shown that several (unidentified) species of bacteria are able to survive under a simulated Martian atmosphere. No work, however, has been reported on the effect of these conditions on the physiology or the virulence of bacteria. In the work recorded here the anaerobic spore-forming organism $\mathrm{Cl}$. botulinum and encapsulated facultative anaerobic organism $K$. pneumoniae were used to determine these effects.

$K$. pneumoniae was grown on blood agar and, after $24 \mathrm{hr}$., was suspended in a sterile 3 per cent lactose solution. $\mathrm{Cl}$. botulinum spores were grown anaerobically in trypticase broth for 7 days and afterwards heated at $85^{\circ} \mathrm{C}$. for $10 \mathrm{~min}$.

Suspensions of the organisms or the spores were distributed in $0 \cdot 5 \cdot \mathrm{ml}$. portions into sterile test tubes, which were constricted $1 \frac{1}{2}$ in. from the top. and contained $5 \mathrm{gm}$. of crushed lava. A group of 12 tubes was lyophilized for $15-20 \mathrm{hr}$. and placed under absolute vacuum. These tubes were sealed and divided into two sub-groups of 6 each. One sub-group was maintained at a constant temperature of $25^{\circ} \mathrm{C}$. and the othor at $25^{\circ} \mathrm{C}$. for $16 \mathrm{hr}$. and $-25^{\circ} \mathrm{C}$. for $8 \mathrm{hr}$. in an alternating cycle. The same procedure was followed with a second and a third group of 12 tubes. Nitrogen was flushed through the second group and the final pressure adjusted to $65 \mathrm{~mm}$. mercury, and air (65 mm. mercury) was used instead of nitrogen in the third group.

The tubes were cracked open at various intervals of 4 days-10 months. To determine viability, the contents were poured and washed into bottles containing nutrient broth, and further serial dilutions wero made in broth. The $K$. pneumoniae cell counts were made on blood agar base pour plates. The $\mathrm{Cl}$. Table 1 . Survina of $K$. pneumoniae in a Sigclated Martia

Environmental conditions $\quad$ No. of organisms $/ 5 \mathrm{gm}$. la va* Atmo- Daily After 4 After 6 After 4 After 6 After 8 sphere temperature days weeks montlis months months Vacuum $\begin{array}{llllll}24 \mathrm{hr} . \text { at } 25^{\circ} \mathrm{C} . & - & 46 \times 10^{5} & 100 & 100 & 10 \\ 16 \mathrm{hr} \text { at } 25^{\circ} \mathrm{C} & 20 \times 10^{6} & 40 \times 10^{5} & 100 & 100 & 10\end{array}$ $\begin{array}{rlllll}\text { Nitrogen } 24 \mathrm{hr} \text {. at } 25^{\circ} \mathrm{C} \text {. } & - & 35 \times 10^{7} & 25 \times 10^{3} & 90 \times 10^{5} & 90 \times 10^{4} \\ 16 \mathrm{hr} \text {. at } 25^{\circ} \mathrm{C} \text {. } & 18 \times 10^{7} & 40 \times 10^{7} & 22 \times 10^{5} & 15 \times 10^{5} & 10\end{array}$ 8 hr. at $-25^{\circ} \mathrm{C}$. Air 24 hr.at $25^{\circ} \mathrm{C}$. - $18 \times 10^{7} 5.6 \times 10^{6} 10 \times 10^{8} 20 \times 10^{*}$ * Initial counts on the order of $10^{\circ}$.

botulinum spores were counted by seeding heart infusion agar in Prickett tubes. To determine the virulence of $K$. pneumoniae, mice were injected intraperitoneally with $0 \cdot 1 \cdot-0 \cdot 2 \mathrm{ml}$. of various dilutions and observed for 14 days.

Table 1 shows the survival of $K$. pneumoniae. Conditions of vacuum and alternating temperature were detrimental to survival. While the viability of the organisms in nitrogen and air at a constant temperature appeared to be unchanged, the $L D_{50}$ values showed that virulence decreased considerably. $K$. pneumoniae freshly isolated from an animal has an $L D_{50}$ of 200 cells. The $L D_{50}$ after 6 weeks under vacuum was 2,800 cells, and after 6 weeks under nitrogen 29,000. The cell count remained almost constant after 6 weeks with those cells maintained in air or nitrogen atmospheres. However, the virulence of the organism had markedly decreased.

Table 2 shows that $C l$. botulinum spores were still viable after 10 months. Constant temperature was less favourable to growth than alternating temperature.

Table 2. SURvival of $d$, botulinum IX a SimulateI Martias

\begin{tabular}{|c|c|c|c|c|}
\hline \multirow[b]{2}{*}{ Atmosphere } & \multicolumn{4}{|c|}{ ENVIRONMENT } \\
\hline & $\begin{array}{c}\text { Daily } \\
\text { temperature }\end{array}$ & $\begin{array}{l}\text { After } \\
1 \text { month }\end{array}$ & $\begin{array}{l}\text { After } \\
6 \text { months }\end{array}$ & $\begin{array}{l}\text { After } \\
10 \text { months }\end{array}$ \\
\hline Vacuum & $\begin{array}{l}24 \mathrm{hr} \text { at } 25^{\circ} \mathrm{C} \text {. } \\
16 \mathrm{hr} \text { at } 25^{\circ} \mathrm{C} \text {. } \\
8 \mathrm{hr} \text {, at }-25^{\circ} \mathrm{C} \text {. }\end{array}$ & $\begin{array}{l}20 \times 10^{6} \\
17 \times 10^{6}\end{array}$ & $\begin{array}{l}13 \times 10^{5} \\
78 \times 10^{5}\end{array}$ & $\begin{array}{l}58 \times 10^{3} \\
29 \times 10^{6}\end{array}$ \\
\hline Nitrogen & $\begin{array}{l}24 \mathrm{hr} \text {. at } 25^{\circ} \mathrm{C} \text {. } \\
16 \mathrm{hr} \text {. at } 25^{\circ} \mathrm{C} \text {. } \\
8 \mathrm{hr} \text {, at }-25^{\circ} \mathrm{C} \text {. }\end{array}$ & $\begin{array}{l}19 \times 10^{6} \\
29 \times 10^{8}\end{array}$ & $\begin{array}{l}16 \times 10^{3} \\
20 \times 10^{3}\end{array}$ & $\begin{array}{l}27 \times 10^{6} \\
53 \times 10^{-5}\end{array}$ \\
\hline Air & $\begin{array}{l}24 \mathrm{hr} \text { at } 25^{\circ} \mathrm{C} . \\
16 \mathrm{hr} \text { at } 25^{\circ} \mathrm{C} \text {. } \\
8 \mathrm{hr} \text {. at }-25^{\circ} \mathrm{C} \text {. }\end{array}$ & $\begin{array}{l}32 \times 10^{6} \\
33 \times 10^{3}\end{array}$ & $\begin{array}{l}90 \times 10^{3} \\
90 \times 10^{4}\end{array}$ & $\begin{array}{l}66 \times 10^{3} \\
53 \times 10^{4}\end{array}$ \\
\hline
\end{tabular}

Thus the results of this work show that an encapsulated, facultative anaerobic organism such as $K$. pneumoniae will survive under Martian conditions for a few months and that it will be less virulent than the freshly isolated organism. Spores of anaerobic organisms such as $\mathrm{Cl}$. botulinum and perhaps the tetanus and gangrene organisms will survive the Martian atmosphere.

\section{ERvin HawryLewicz \\ BetTy Gowdy RICHARD EHRIICH}

Armour Research Foundation

of Illinois Institute of Technology, Technology Center, Chicago 16.

'Kuiper, G. P., The Atmospheres of the Earth and Plunets (Univ. of Chicago Press, 1952).

${ }^{2}$ Sinton, W. M., Science, 130, 1234 (1959).

${ }^{3}$ Miller, S. L., and Urey, H. C., Science, 130, 245 (1959).

Oparin, A. I., The Origin of Life, third ed. (Academic Press, New York, ig57).

${ }^{5}$ Huang, S. S., Sci. Amer., 202, No. 4, 55 (1960). "Fulton, J. D., Physics and Medicine of the Atmosphere and Space, York, 1959).

'Davis, I., and Fulton, J. D., Aeromed. Rev., 2 (1959). 